\title{
POLARIZATION SELECTION OF NAVIGATION OBJECTS LOCATED IN THE ZONE OF ATMOSPHERIC FORMATIONS
}

\section{ПОЛЯРИЗАЦІЙНИЙ ВИБІР НАВІГАЦІЙНИХ ОБ'ЄКТІВ, РОЗМІЩЕННИХ В ЗОНІ АТМОСФЕРНИХ УТВОРЕНЬ}

\author{
D. Korban, $P h D$ \\ National University «Odessa Maritime Academy», Ukraine
}

\begin{abstract}
The possibility of polarization selection implementation of the navigation objects located in the area of atmospheric-formations by the ship single-position radiolocation station (radar) is considered. The polarization selection of the navigational objects located in the area of atmospheric formations is based on their different electro-physical parameters, which from them electromagnetic waves of different polarization. The process of the polarization selection is controlled by the appropriate choice of polarization, which irradiates the objects of the electromagnetic wave, given the actual Stokes parameters. The interference performance of the objects, observed by the ship's radar, is represented by means of the Mueller matrices (i.e., dissociation), which have 16 coefficients. The determination of the matrix coefficients of the atmospheric formation dissociation is carried out by their differentiation or integration by the method of Pikar (i.e., the successive approximation). The coefficients of the atmospheric formation matrix are shown to be variable functions of time, endpoints for all values of the analyzed interval. The division of the time interval into segments, in which the coefficients of the matrix are considered constant, allows them to be calculated using Baker's formula. The practical implementation of the polarization selection of the navigation objects located in the zone of atmospheri formations; is based on the measurement of the coefficients of the dispersion matrix by the intermittent sampling of objects by non-polarized wave, double line wave, and circular polarization.
\end{abstract}

Keywords: polarization selection, navigation object, atmospheric objects, electromagnetic wave, Mueller matrix, Stokes parameters, sequential approximation method, differentiation and integration operators, dynamic system, electrophysical parameters of objects, reflecting property of objects.

\section{PЕФЕРАТ}

Здійснено реалізацію моделі взаємодії суднової РЛС із зовнішнім середовищем при однопозииійній радіолокаиії, коли навігащійний об'єкт перебуває у зоні атмосферного утворення. Електромагнітна хвиля на випромінювання і прийом представлена у вигляді двох матриць, щуо складаються з дійсних енергетичних параметрів Стокса, а відбиваючі властивості атмосферного утворення характеризуються 16 коефіцієнтами, що об'єднані в матрицю Мюллера яка складається з чотирьох стовпџів $і$ чотирьох рядків. Відбита хвиля представлена чотирма параметрами Стокса, як поле, індуковане невідомим розподілом відбивачів атмосферного утворення, при їх опроміненні електромагнітними хвилями чотирьох поляризачій у лінійному та круговому базисах. Визначення коефіцієнтів матриці розсіювання атмосферного утворення здійснюється диференціюванням або інтегруванням за методом Пікара (послідовним наближенням). Показано, щฺо коефімієнти матриці розсіювання атмосферного утворення є змінними функціями часу, кінцевими для всіх значень аналізованого інтервалу. Зроблено поділ часового проміжку на відрізки, у яких коефіцієнти матриці розглядаються як постійні, щзо дозволяе їх обчислити за допомогою формули Бейкера. Практична реалізачія моделі взаємодії суднової РЛС з атмосферним середовищем 
заснована на вимірюванні коефіцієнтів матриці розсіювання при послідовному опроміненні атмосферного утворення неполяризованою хвилею, хвилею двох лінійних та кругової поляризачій.

Ключові слова: модель взаємодії, суднова РЛС, атмосферне середовище, навігаційний об'єкт, електромагнітна хвиля, матриця Мюллера, параметри Стокса, метод послідовних наближень, оператори диференціювання та інтегрування, радіолокаційний канал, динамічна система.

\section{tasks \\ Statement of the problem in general terms and its relationship to scientific and practical}

When the ship's radar is activated, a signal is received by the input of the decision-making device, the source of the signal is a navigation radar object in the absence of the atmospheric environment signal. The radar information channel model describes the process of transforming the signal characteristics along the trace from the transmitter to the object, from the object to the receiver and then to the device for the processing of the received signals. In this case, all processes are set in discrete time.

The result of the interaction of the wave emitted by the ship's radar antenna with the atmospheric formation, in which the navigation object is located, is obtained by multiplying the Stokes vector of the emitted wave by the Muller matrix of the atmospheric formation-As a result, the Stokes vector of the reflected wave is calculated.

To analyze the principle of transition when describing the operation of the ship's radar from continuous time to discrete time, a mathematical structure called the dynamic system is used, which is an abstract model and satisfies the principle of causality. In this case, the most important class of dynamic systems at the continuous time of their installation are smooth dynamic systems, described by the transition function of the state.

\section{Analysis of recent advances and publications that have begun to address this problem, and highlighting unresolved issues}

The theory of the information channel was formulated by V.A. Potyekhin, V.C. Dulevich, A.P. Rodimov, D.A. Middleton, E. M. Kennaugh, J.R. Huynen, W. M. Boerner- etc. The obtained results on the state of the radar channel theory are presented in [1]. The Polarization of the radar signals is fully considered in [2-4]. The parametric representation of the polarization of radio waves is based on the four real parameters, introduced by Stokes, which have the intensity dimension. Since the interaction of the emitted wave with the atmospheric object occurs incoherently, the Muller matrix is used, the formalism of which is based on the representation of the polarization state of the wave by the Stokes vector and the representation of the scattering properties of the atmospheric formation by 16 real coefficients.

The result of the interaction of the wave emitted by the ship's radar antenna with the atmospheric formation in which the navigation object is located is obtained by multiplying the Stokes vector of the emitted wave by the Muller matrix of the atmospheric formation, a result, the Stokes vector of the reflected wave is calculated.

\section{Formulation of the goals of the article (problem statement)}

The purpose of this article is to present a model of the interaction of the ship's radar with the atmospheric environment, taking into account the reaction of the atmospheric environment to the operation of the ship's radar.

\section{results}

Statement of the material of the study with the justification of the obtained scientific

Consider a smooth dynamic system described by a transient state function, i.e.: 


$$
\frac{d S(t)}{d t}=S\left\{S(t), U_{6 x}(t), t\right\}
$$

and the output display:

$$
U_{\text {вux }}(t)=U_{\text {вux }}\{S(t)\}
$$

In terms of the dynamic system (1), (2), the input impact changes the state of the ship's radar, which determines the output signal.

For smooth dynamic systems, in which the linearity of the transient state function and the output mapping by their signal arguments is ensured, equations (1) and (2) are written in the form:

$$
\begin{aligned}
& \frac{d S(t)}{d t}=A_{t} S(t)+B_{t} U_{\text {вих }}(t) ; \\
& U_{\text {вих }}(t)=C_{t} S(t),
\end{aligned}
$$

where $A_{t}, B_{t}, C_{t}$ - matrices, which can depend on time;

$S(t), U_{\text {виx }}(t)$ _ multidimensional vector functions.

Equation (4) is called the equation of state in the theory of the dynamical systems.

Based on the phenomenological description of devices and systems in terms of input and output, the description of the dynamic system is represented by a differential equation that connects the input and output-effects, i.e:

$$
a_{0} \frac{d^{n} U_{B x}(t)}{d t^{n}}+a_{1} \frac{d^{n-1} U_{B x}(t)}{d t^{n-1}}+\ldots+a_{n} U_{\text {вx }}(t)=b_{1} \frac{d^{n-1} U_{\text {вux }}(t)}{d t^{n-1}}+\ldots+b_{n} U_{\text {виx }}(t)
$$

where $U_{\text {вx }}(t)$ и $U_{\text {виx }}(t)$ - multidimensional vectors;

$a_{0}(t), a_{1}(t), \ldots, a_{n}(t), b_{0}(t), b_{1}(t), \ldots, b_{n}(t)$ - matrix coefficients, the dimensionality of which allows us to match the input and output signals into a single equation.

The output equation (3) and the equation of state (4) for the discrete system are written as:

$$
\begin{aligned}
& S_{j+1}=A S_{j}+B U_{\text {вux } j}, \\
& U_{\text {вux } j}=C S_{j},
\end{aligned}
$$

де $A, B, C$ - matrices that do not have an index $\mathrm{t}$ for a discrete system, which indicates the discreteness of time.

Equations (6) and (7) are obtained from (3) and (4) at $U_{\text {sux }}(t)=0, \frac{d}{d t}=A$, and the operator $B_{t}$ (3) is converted into the operator $B=\left(e^{A \delta}-1\right)^{-1} \cdot B=(A)^{-1} \cdot B$, where is $\delta>0$ the sampling step of the system.

Thus, the definition of the dynamic system in terms of the input-output and the standard representation (3), (4), are fully equivalent.

For the ship's radar, two types of descriptions are used:

- Using the dynamic system (1) - (7), corresponding to phenomenological representations that describe devices and systems in terms of input and output;

- by means of the model of interaction of the ship's radar with the external environment, which 
corresponds to purposeful systems.

When describing the ship's radar using the dynamic system, the signals coming to the input of the ship's radar $U_{в x}(t)$ and output signals $U_{в u x}(t)$ are related by matrix equations represented by Stokes energy parameters:

$$
\begin{gathered}
U_{b x}(t)=\left[\begin{array}{c}
S_{16 x}(t) \\
S_{2 b x}(t) \\
S_{3 b x}(t) \\
S_{4 b x}(t)
\end{array}\right], \\
U_{\text {вux }}(t)=\left[\begin{array}{c}
S_{18 u x}(t) \\
S_{2 \text { sux }}(t) \\
S_{3 в u x}(t) \\
S_{4 \text { sux }}(t)
\end{array}\right],
\end{gathered}
$$

When using the model of interaction of the ship's radar with the atmospheric environment, when the atmospheric environment reaction to the operation of the ship's radar during radar observation of navigation objects in conditions of atmospheric interference is considered, the fixed sequence of operators, changing in time, is represented as matrices $\mathrm{T}$, characterizing the set of atmospheric environments (rain of different intensity and phase state):

$$
\begin{aligned}
T_{1} & =\left[\begin{array}{llll}
\alpha_{11}\left(t_{1}\right) & \alpha_{12}\left(t_{1}\right) & \alpha_{13}\left(t_{1}\right) & \alpha_{14}\left(t_{1}\right) \\
\alpha_{21}\left(t_{1}\right) & \alpha_{22}\left(t_{1}\right) & \alpha_{23}\left(t_{1}\right) & \alpha_{24}\left(t_{1}\right) \\
\alpha_{31}\left(t_{1}\right) & \alpha_{32}\left(t_{1}\right) & \alpha_{33}\left(t_{1}\right) & \alpha_{34}\left(t_{1}\right) \\
\alpha_{41}\left(t_{1}\right) & \alpha_{42}\left(t_{1}\right) & \alpha_{43}\left(t_{1}\right) & \alpha_{44}\left(t_{1}\right)
\end{array}\right] ; \\
T_{2} & =\left[\begin{array}{llll}
\alpha_{11}\left(t_{2}\right) & \alpha_{12}\left(t_{2}\right) & \alpha_{13}\left(t_{2}\right) & \alpha_{14}\left(t_{2}\right) \\
\alpha_{21}\left(t_{2}\right) & \alpha_{22}\left(t_{2}\right) & \alpha_{23}\left(t_{2}\right) & \alpha_{24}\left(t_{2}\right) \\
\alpha_{31}\left(t_{2}\right) & \alpha_{32}\left(t_{2}\right) & \alpha_{33}\left(t_{2}\right) & \alpha_{34}\left(t_{2}\right) \\
\alpha_{41}\left(t_{2}\right) & \alpha_{42}\left(t_{2}\right) & \alpha_{43}\left(t_{2}\right) & \alpha_{44}\left(t_{2}\right)
\end{array}\right] ; \\
T_{n} & =\left[\begin{array}{llll}
\alpha_{11}\left(t_{n}\right) & \alpha_{12}\left(t_{n}\right) & \alpha_{13}\left(t_{n}\right) & \alpha_{14}\left(t_{n}\right) \\
\alpha_{21}\left(t_{n}\right) & \alpha_{22}\left(t_{n}\right) & \alpha_{23}\left(t_{n}\right) & \alpha_{24}\left(t_{n}\right) \\
\alpha_{31}\left(t_{n}\right) & \alpha_{32}\left(t_{n}\right) & \alpha_{33}\left(t_{n}\right) & \alpha_{34}\left(t_{n}\right) \\
\alpha_{41}\left(t_{n}\right) & \alpha_{42}\left(t_{n}\right) & \alpha_{43}\left(t_{n}\right) & \alpha_{44}\left(t_{n}\right)
\end{array}\right],
\end{aligned}
$$

where $\alpha_{n n}\left(t_{n}\right)$ - coefficients, which characterize reflecting-effects of atmospheric environment, in which navigation object is located.

Taking into account the equations (8) - (12) for the ship's radar, in general, at any point of time, the main information flow is continuous from input to output, formed by the atmospheric environment and the navigation object. The equation of the main information flow is represented in the form of three matrices: 


$$
\left[\begin{array}{l}
S_{18 x}\left(t_{n}\right) \\
S_{28 x}\left(t_{n}\right) \\
S_{36 x}\left(t_{n}\right) \\
S_{48 x}\left(t_{n}\right)
\end{array}\right]=\left[\begin{array}{llll}
\alpha_{11}\left(t_{n}\right) & \alpha_{12}\left(t_{n}\right) & \alpha_{13}\left(t_{n}\right) & \alpha_{14}\left(t_{n}\right) \\
\alpha_{21}\left(t_{n}\right) & \alpha_{22}\left(t_{n}\right) & \alpha_{23}\left(t_{n}\right) & \alpha_{24}\left(t_{n}\right) \\
\alpha_{31}\left(t_{n}\right) & \alpha_{32}\left(t_{n}\right) & \alpha_{33}\left(t_{n}\right) & \alpha_{34}\left(t_{n}\right) \\
\alpha_{41}\left(t_{n}\right) & \alpha_{42}\left(t_{n}\right) & \alpha_{43}\left(t_{n}\right) & \alpha_{44}\left(t_{n}\right)
\end{array}\right] \cdot\left[\begin{array}{l}
S_{1 \text { виux }}\left(t_{n}\right) \\
S_{2 \text { вих }}\left(t_{n}\right) \\
S_{3 \text { вих }}\left(t_{n}\right) \\
S_{48 u x}\left(t_{n}\right)
\end{array}\right] .
$$

The syntactic approach to the research of processes or information received by the ship's radar is aimed at the structural analysis of information, i.e., removing uncertainty in the incoming message about the navigation object taking into account the spatial, temporal, and polarization structures of the signal. The semantic approach involves the analysis of the semantic content of the information, and pragmatic - to assess the usefulness and value of the information obtained. The system of signals is considered as some mathematical construction, reflecting the ability to transform, transmit, receive, and process information about the observed situation.

The presence of a navigational object in the area of the atmospheric formation is considered. The electromagnetic wave emitted by the antenna of the ship's radar and received at reflection from the precipitation zone, in which the navigation object is located, is represented by four valid Stokes parameters $S_{1}, S_{2}, S_{3}, S_{4}$ :

$$
\begin{gathered}
\mathrm{S}_{1}=I_{x+} I_{y}=I_{+\pi / 4}+I_{-\pi / 4}=I_{n} I_{n} ; \\
\mathrm{S}_{2}=I_{x_{-}} I_{y} ; \\
\mathrm{S}_{3}={ }_{+\pi / 4}+I_{-\pi / 4} ; \\
\mathrm{S}_{4}=I_{n_{-}} I_{n} .
\end{gathered}
$$

Stokes parameters are called parametric. They describe the polarization of the wave field by means of a system of real parameters quadratic with respect to the field strength. Wave intensities are denoted by $I_{x}, I_{y}, I_{+\pi / 4}, I_{-\pi / 4}, I_{n}, I_{n}$, where the first four relate to the linear polarizations and the last two to the circular polarizations of left and right rotation.

The reflecting properties of the radar volume of the atmospheric formation are characterized by the coefficients $\left(\alpha_{11} \ldots \alpha_{44}\right)$. The electromagnetic wave on radiation and on reception is represented in the form of two matrices consisting of Stokes parameters, and reflecting properties of the radar volume of the atmospheric formation are also represented in the form of matrix consisting of 16 coefficients. Then the equation of relation between the emitted wave and the reflected wave and the reflecting properties of the radar volume, are written in the form:

$$
\left[\begin{array}{l}
S_{1 \text { sid }} \\
S_{2 \text { sid }} \\
S_{3 \text { Bid }} \\
S_{4 \text { sid }}
\end{array}\right]=\left[\begin{array}{llll}
\alpha_{11} & \alpha_{12} & \alpha_{13} & \alpha_{14} \\
\alpha_{21} & \alpha_{22} & \alpha_{23} & \alpha_{24} \\
\alpha_{31} & \alpha_{32} & \alpha_{33} & \alpha_{34} \\
\alpha_{41} & \alpha_{42} & \alpha_{43} & \alpha_{44}
\end{array}\right] \cdot\left[\begin{array}{c}
S_{1 \text { вun }} \\
S_{2 \text { вun }} \\
S_{3 \text { sun }} \\
S_{4 \text { вun }}
\end{array}\right],
$$

or as four linear equations:

$$
\begin{aligned}
& S_{1 \text { вid }}=\alpha_{11} S_{1 \text { виn }}+\alpha_{12} S_{2 \text { виn }}+\alpha_{13} S_{3 \text { виn }}+\alpha_{14} S_{4 \text { ви }} \\
& S_{2 \text { вid }}=\alpha_{21} S_{1 \text { вип }}+\alpha_{22} S_{2 \text { вии }}+\alpha_{23} S_{3 \text { вии }}+\alpha_{24} S_{4 \text { вии }} \\
& S_{3 \text { від }}=\alpha_{31} S_{1 \text { вии }}+\alpha_{32} S_{2 \text { вии }}+\alpha_{33} S_{3 \text { вии }}+\alpha_{34} S_{4 \text { вии }} \\
& S_{4 \text { sid }}=\alpha_{41} S_{1 \text { вии }}+\alpha_{42} S_{2 \text { вии }}+\alpha_{43} S_{3 \text { вии }}+\alpha_{44} S_{4 \text { вии }} \text {. }
\end{aligned}
$$

Determination of the reflecting properties of a particular type of the atmospheric formation is performed by theoretical or experimental investigation of the matrix coefficients $(\alpha 11 \ldots \alpha 44)$, which 
carry all the information about the physical properties of the atmospheric formation. Four Stokes parameters of the emitted wave of four polarizations, and four Stokes parameters of the reflected wave for each type of polarization of the emitted wave are used in modeling the reflecting properties of the atmospheric formation.

Then during irradiation of the atmospheric formation (precipitation zone) with a navigation object located in it by the electromagnetic wave of the linear vertical or horizontal polarization, equation (15) is as follows:

$$
\left[\begin{array}{l}
S_{1 \text { вiid }} \\
S_{2 \text { sid }} \\
S_{3 \text { Bii }} \\
S_{4 \text { sid }}
\end{array}\right]=\left[\begin{array}{llll}
\alpha_{11} & \alpha_{12} & 0 & 0 \\
\alpha_{21} & \alpha_{22} & 0 & 0 \\
\alpha_{31} & \alpha_{32} & 0 & 0 \\
\alpha_{41} & \alpha_{42} & 0 & 0
\end{array}\right] \cdot\left[\begin{array}{l}
S_{1 \text { вй }} \\
S_{2 \text { виn }} \\
0 \\
0
\end{array}\right],
$$

or in the form of:

$$
\left[S_{\text {вid }}\right]=[\alpha] \cdot\left[S_{\text {вип.л.в.(л.г.) }}\right]
$$

and the matrix of coefficients $[\alpha]$ are written as follows:

$$
[\alpha]=\left[\begin{array}{ll}
\alpha_{11} & \alpha_{12} \\
\alpha_{21} & \alpha_{22} \\
\alpha_{31} & \alpha_{32} \\
\alpha_{41} & \alpha_{42}
\end{array}\right]
$$

The Stokes parameters of the emitted and reflected wave are not independent, there are four linear equations between them:

$$
\left.\begin{array}{l}
S_{1 \text { вid }}=\alpha_{11} S_{1 \text { вun }}+\alpha_{12} S_{2 \text { вun }} \\
S_{2 \text { вid }}=\alpha_{21} S_{1 \text { вun }}+\alpha_{22} S_{2 \text { вun }} \\
S_{3 \text { вid }}=\alpha_{31} S_{1 \text { вun }}+\alpha_{32} S_{2 \text { вun }} \\
S_{4 \text { вid }}=\alpha_{41} S_{1 \text { вun }}+\alpha_{42} S_{2 \text { вun }}
\end{array}\right\},
$$

which solution allows us to determine the coefficients of the matrix (19).

When irradiating the precipitation zone, in which the navigation object is located, by a linear polarization wave with the slope of the electric vector at an angle of $45^{\circ}$, the equation (15) has/takes the following form:

Or in the form of:

$$
\left[\begin{array}{l}
S_{1 \text { вid }} \\
S_{2 \text { sid }} \\
S_{3 \text { sid }} \\
S_{4 \text { sid }}
\end{array}\right]=\left[\begin{array}{llll}
\alpha_{11} & 0 & \alpha_{13} & 0 \\
\alpha_{21} & 0 & \alpha_{23} & 0 \\
\alpha_{31} & 0 & \alpha_{33} & 0 \\
\alpha_{41} & 0 & \alpha_{43} & 0
\end{array}\right] \cdot\left[\begin{array}{l}
S_{1 \text { вии }} \\
0 \\
S_{3 \text { вun }} \\
0
\end{array}\right],
$$

$$
\left[S_{\text {вid }}\right]=[\alpha] \cdot\left[S_{\text {виn.л. } 45^{\circ}}\right]
$$

and the matrix of coefficients $[\alpha]$ are written as follows: 


$$
[\alpha]=\left[\begin{array}{ll}
\alpha_{11} & \alpha_{13} \\
\alpha_{21} & \alpha_{23} \\
\alpha_{31} & \alpha_{33} \\
\alpha_{41} & \alpha_{43}
\end{array}\right] .
$$

From (21) the linear relations between the Stokes parameters are represented in the form:

$$
\left.\begin{array}{l}
S_{1 \text { вid }}=\alpha_{11} S_{1 \text { вии }}+\alpha_{13} S_{3 \text { вun }} \\
S_{2 \text { вid }}=\alpha_{21} S_{1 \text { вun }}+\alpha_{23} S_{3 \text { виn }} \\
S_{3 \text { вid }}=\alpha_{31} S_{1 \text { вun }}+\alpha_{33} S_{3 \text { вии }} \\
S_{4 \text { вid }}=\alpha_{41} S_{1 \text { вun }}+\alpha_{43} S_{3 \text { виn }}
\end{array}\right\} .
$$

When irradiating the precipitation zone, in which a navigational object is located, by a circular polarization wave of left or right rotation of the electric vector, the equation (21) has/takes the following form:

$$
\left[\begin{array}{l}
S_{1 \text { sid }} \\
S_{2 \text { вid }} \\
S_{3 \text { sid }} \\
S_{4 \text { sid }}
\end{array}\right]=\left[\begin{array}{llll}
\alpha_{11} & 0 & 0 & \alpha_{14} \\
\alpha_{21} & 0 & 0 & \alpha_{24} \\
\alpha_{31} & 0 & 0 & \alpha_{34} \\
\alpha_{41} & 0 & 0 & \alpha_{44}
\end{array}\right] \cdot\left[\begin{array}{l}
S_{1 \text { вun }} \\
0 \\
0 \\
S_{4 \text { sun }}
\end{array}\right],
$$

as well as in the form of three matrices:

$$
\left[S_{\text {вid }}\right]=[\alpha] \cdot\left[S_{\text {вun.кp. }}\right],
$$

the coefficient matrix $[\alpha]$ is written as follows:

$$
[\alpha]=\left[\begin{array}{ll}
\alpha_{11} & \alpha_{14} \\
\alpha_{21} & \alpha_{24} \\
\alpha_{31} & \alpha_{34} \\
\alpha_{41} & \alpha_{44}
\end{array}\right]
$$

The following linear relationships exist between the Stokes parameters of the emitted and reflected wave:

$$
\left.\begin{array}{l}
S_{1 \text { вid }}=\alpha_{11} S_{1 \text { вun }}+\alpha_{14} S_{4 \text { вun }} \\
S_{2 \text { вid }}=\alpha_{21} S_{1 \text { вun }}+\alpha_{24} S_{4 \text { вun }} \\
S_{3 \text { вid }}=\alpha_{31} S_{1 \text { вun }}+\alpha_{34} S_{4 \text { вun }} \\
S_{4 \text { вid }}=\alpha_{41} S_{1 \text { виn }}+\alpha_{44} S_{4 \text { вun }}
\end{array}\right\} .
$$

In the ship's radar the method of the radar observation of a navigation object is used in a singleposition radar, when the transmitting and receiving antennas are located in one point of space, and the coefficient matrix is a backscattering matrix: 


$$
[\alpha]=\left[\begin{array}{llll}
\alpha_{11} & \alpha_{12} & \alpha_{13} & \alpha_{14} \\
\alpha_{21} & \alpha_{22} & \alpha_{23} & \alpha_{24} \\
\alpha_{31} & \alpha_{32} & \alpha_{33} & \alpha_{34} \\
\alpha_{41} & \alpha_{42} & \alpha_{43} & \alpha_{44}
\end{array}\right]
$$

The backscattering matrix characterizes the scattering properties of the radar observation object in the opposite directions of propagation of the radiated (incident on the object) and scattered by the object (reflected) electromagnetic wave, i.e. the scattering operator in terms of transformation of polarization of the wave by the object during backscattering, relative to the linear and circular bases.

The elements of the matrix (29) ${ }^{\alpha_{i j}}$ are the functions of one variable $t$, i.e

$$
\alpha_{i j}=\alpha_{i j}(t)
$$

The derivative of the matrix (29) is defined by the following relation

$$
\frac{d}{d t}[\alpha]=\left[\begin{array}{cccc}
\frac{d \alpha_{11}}{d t} & \frac{d \alpha_{12}}{d t} & \frac{d \alpha_{13}}{d t} & \frac{d \alpha_{14}}{d t} \\
\frac{d \alpha_{21}}{d t} & \frac{d \alpha_{22}}{d t} & \frac{d \alpha_{23}}{d t} & \frac{d \alpha_{24}}{d t} \\
\frac{d \alpha_{31}}{d t} & \frac{d \alpha_{32}}{d t} & \frac{d \alpha_{33}}{d t} & \frac{d \alpha_{34}}{d t} \\
\frac{d \alpha_{41}}{d t} & \frac{d \alpha_{42}}{d t} & \frac{d \alpha_{43}}{d t} & \frac{d \alpha_{44}}{d t}
\end{array}\right]
$$

The integral of the matrix (29) can be represented as:

$$
\int_{t_{0}}^{t}[\alpha] d t=\left[\begin{array}{llll}
\int_{t_{0}}^{t} \alpha_{11} d t & \int_{t_{0}}^{t} \alpha_{12} d t & \int_{t_{0}}^{t} \alpha_{13} d t & \int_{t_{0}}^{t} \alpha_{14} d t \\
\int_{t_{0}}^{t} \alpha_{21} d t & \int_{t_{0}}^{t} \alpha_{22} d t & \int_{t_{0}}^{t} \alpha_{23} d t & \int_{t_{0}}^{t} \alpha_{24} d t \\
\int_{t_{0}}^{t} \alpha_{31} d t & \int_{t_{0}}^{t} \alpha_{32} d t & \int_{t_{0}}^{t} \alpha_{33} d t & \int_{t_{0}}^{t} \alpha_{34} d t \\
\int_{t_{0}}^{t} \alpha_{41} d t & \int_{t_{0}}^{t} \alpha_{42} d t & \int_{t_{0}}^{t} \alpha_{43} d t & \int_{t_{0}}^{t} \alpha_{44} d t
\end{array}\right] .
$$

Then the derivative of the matrix (29) are written in the form: 


$$
\frac{d}{d t}[\alpha]=\left[\begin{array}{ll}
\frac{d \alpha_{11}}{d t} & \frac{d \alpha_{12}}{d t} \\
\frac{d \alpha_{21}}{d t} & \frac{d \alpha_{22}}{d t} \\
\frac{d \alpha_{31}}{d t} & \frac{d \alpha_{32}}{d t} \\
\frac{d \alpha_{41}}{d t} & \frac{d \alpha_{42}}{d t}
\end{array}\right],
$$

and its integral is defined by the relation:

$$
\int_{t_{0}}^{t}[\alpha] d t=\left[\begin{array}{ll}
\int_{t_{0}}^{t} \alpha_{11} d t & \int_{t_{0}}^{t} \alpha_{12} d t \\
\int_{t_{0}}^{t} \alpha_{21} d t & \int_{t_{0}}^{t} \alpha_{22} d t \\
\int_{t_{0}}^{t} \alpha_{31} d t & \int_{t_{0}}^{t} \alpha_{32} d t \\
\int_{t_{0}}^{t} \alpha_{41} d t & \int_{t_{0}}^{t} \alpha_{42} d t
\end{array}\right] .
$$

The derivative of the matrix (19) are written in the form:

$$
\frac{d}{d t}[\alpha]=\left[\begin{array}{cc}
\frac{d \alpha_{11}}{d t} & \frac{d \alpha_{13}}{d t} \\
\frac{d \alpha_{21}}{d t} & \frac{d \alpha_{23}}{d t} \\
\frac{d \alpha_{31}}{d t} & \frac{d \alpha_{33}}{d t} \\
\frac{d \alpha_{41}}{d t} & \frac{d \alpha_{43}}{d t}
\end{array}\right],
$$

and its integral in the form:

$$
\int_{t_{0}}^{t}[\alpha] d t=\left[\begin{array}{ll}
\int_{t_{0}}^{t} \alpha_{11} d t & \int_{t_{0}}^{t} \alpha_{13} d t \\
\int_{t_{0}}^{t} \alpha_{21} d t & \int_{t_{0}}^{t} \alpha_{23} d t \\
\int_{t_{0}}^{t} \alpha_{31} d t & \int_{t_{0}}^{t} \alpha_{33} d t \\
\int_{t_{0}}^{t} \alpha_{41} d t & \int_{t_{0}}^{t} \alpha_{43} d t
\end{array}\right] .
$$

The derivative of the matrix (27) are written in the form: 


$$
\frac{d}{d t}[\alpha]=\left[\begin{array}{ll}
\frac{d \alpha_{11}}{d t} & \frac{d \alpha_{14}}{d t} \\
\frac{d \alpha_{21}}{d t} & \frac{d \alpha_{24}}{d t} \\
\frac{d \alpha_{31}}{d t} & \frac{d \alpha_{34}}{d t} \\
\frac{d \alpha_{41}}{d t} & \frac{d \alpha_{44}}{d t}
\end{array}\right],
$$

and its integral in the form:

$$
\int_{t_{0}}^{t}[\alpha] d t=\left[\begin{array}{ll}
\int_{t_{0}}^{t} \alpha_{11} d t & \int_{t_{0}}^{t} \alpha_{14} d t \\
\int_{t_{0}}^{t} \alpha_{21} d t & \int_{t_{0}}^{t} \alpha_{24} d t \\
\int_{t_{0}}^{t} \alpha_{31} d t & \int_{t_{0}}^{t} \alpha_{34} d t \\
\int_{t_{0}}^{t} \alpha_{41} d t & \int_{t_{0}}^{t} \alpha_{44} d t
\end{array}\right] .
$$
written

In general terms, the solution of the system of linear differential equations of the first order is

$$
\begin{aligned}
& \frac{d S_{18 i \partial}}{d t}=\alpha_{11} S_{1 \text { виn }}+\alpha_{12} S_{2 \text { вии }}+\alpha_{13} S_{3 \text { вии }}+\alpha_{14} S_{4 \text { вй }} \\
& \frac{d S_{2 \text { sid }}}{d t}=\alpha_{21} S_{1 \text { вun }}+\alpha_{22} S_{2 \text { вun }}+\alpha_{23} S_{3 \text { виn }}+\alpha_{24} S_{4 \text { вun }} \\
& \frac{d S_{3 \text { вi⿱ }}}{d t}=\alpha_{31} S_{1 \text { вии }}+\alpha_{32} S_{2 \text { вии }}+\alpha_{33} S_{3 \text { вии }}+\alpha_{34} S_{4 \text { вии }} \\
& \frac{d S_{4 \text { вid }}}{d t}=\alpha_{41} S_{1 \text { вй }}+\alpha_{42} S_{2 \text { вии }}+\alpha_{43} S_{3 \text { вии }}+\alpha_{44} S_{4 \text { вии }}
\end{aligned}
$$

To determine the coefficients of the system of equations (39) $\left(\alpha_{11} \ldots \alpha_{44}\right)$, it is necessary to have information about Stokes parameters $S_{18 i \partial}, S_{28 i \partial}, S_{3 \varepsilon i \partial}, S_{48 i \partial}$, when the radar object of the ship's radar observation by electromagnetic waves of four fixed polarizations, considered above or unpolarized wave, linear vertical (horizontal) polarization wave, linear wave with a field vector angle of $45^{\circ}$ and circular polarization wave (right or left rotation vector). However, the Stokes parameters of the reflected wave are related to the microstructure of the reflecting object, and their theoretical calculation is a difficult task. Denoting by $D$ the differentiation operation, the system of equations (39) are written using the matrix notations as follows:

$$
\left[D S_{\text {вid }}\right]=[\alpha] \cdot\left[S_{\text {виn }}\right] \text {. }
$$

The Stokes parameters of the electromagnetic wave radiated by the ship's radar antenna do not depend on time $t$, and are taken equal to one. Then equation (40)-takes the following form:

$$
\left[D S_{6 i d}\right]=[\alpha]
$$


or

$$
\frac{d}{d t}\left(S_{\text {sid }}\right)=[\alpha]
$$

Under the initial conditions for the reflected wave $t=t_{0}$, the Stokes parameters of the reflected wave -are generally written as follows:

$$
\left[S_{\text {sid }}\right]=\left[S_{\text {sid }}\left(t_{0}\right)\right]
$$

and the integral equation is written:

$$
\left[S_{\text {sid }}(t)\right]=\left[S_{\text {sid }}\left(t_{0}\right)\right]+\int_{t_{0}}^{t}[\alpha(t)]\left[S_{\text {sid }}(t)\right] d t \text {. }
$$

The solution of the equation (44) can be done by the successive approximation (Picard method) with the introduction of operator $Q$, which defines the integration operation $\int_{t_{0}}^{t} \alpha(t) d t$, i.e. allows to obtain [5]:

$$
\left[S_{\text {sid }}(t)\right]=\{[1]+Q[\alpha]+Q[\alpha] Q[\alpha]+Q[\alpha] Q[\alpha] Q[\alpha]+\ldots\}\left[S_{\text {вid }}\left(t_{0}\right)\right]
$$

The integration operator $\Omega^{t_{0}, t}$, allows to obtain the result of its operation produced over the matrix in the form:

$$
\Omega^{t_{0}, t}=\left\{[1]+\int_{t_{0}}^{t}[\alpha] d t+\int_{t_{0}}^{t}[\alpha] d t \int_{t_{0}}^{t}[\alpha] d t+\int_{t_{0}}^{t}[\alpha] d t \int_{t_{0}}^{t}[\alpha] d t \int_{t_{0}}^{t}[\alpha] d t+\ldots\right\}
$$

As a result, the solution of the system (43) is written in the form:

$$
\left[S_{\text {Bid }}(t)\right]=\Omega^{t_{0}, t}[\alpha]\left[S_{\text {вid }}\left(t_{0}\right)\right] .
$$
result:

Differentiating the integral operator $\Omega^{t_{0}, t}[\alpha]$ with respect to $t$, allows us to obtain the following

$$
\frac{d}{d t} \Omega^{t_{0}, t}[\alpha]=[\alpha] \Omega^{t_{0}, t}[\alpha]
$$

However, the coefficients $\alpha$ are functions of the variable $t$, finite for all values of the interval $\left(t_{0}, t\right)$, so the calculation $\Omega^{t_{0}, t}[\alpha(t)]$ is difficult and to obtain an approximate solution the interval $\left(t_{0}\right.$ ,$t$ ) is divided into segments in which the coefficients $\alpha$ are treated as constants and then (48) is written in the form:

$$
\Omega^{t_{0}, t}[\alpha]=e^{[\alpha]\left(t-t_{0}\right)},
$$

as in this case: 


$$
Q[\alpha] Q[\alpha] Q[\alpha] \ldots Q[\alpha]=\frac{\left(t-t_{0}\right)^{n}}{n !}[\alpha]^{n}
$$

And taking into account (49), equation (47) is written as:

$$
\left[S_{\text {sid }}(t)\right]=e^{[\alpha]\left(t-t_{0}\right)}\left[S_{\text {sid }}\left(t_{0}\right)\right]
$$

The matrix $e^{[\alpha]\left(t-t_{0}\right)}$ is calculated using the Backer formula [5].

The practical implementation of the determination of the reflective properties of the radar objects of the ship's radar observation (elements of scattering matrix $\alpha_{11} \ldots \alpha_{44}$ ) is easily performed by irradiation of the observed object by the ship's radar, non-polarized wave, linear vertical (horizontal) polarization wave, linearly polarized wave with an angle of inclination of field vector in $45^{\circ}$ relative to the horizontal axis of the selected linear basis and circular polarization wave (right or left rotation of vector).

When irradiating an atmospheric object with an unpolarized wave, the equation (15) is written as follows:

$$
\left[\begin{array}{l}
S_{16 i d}^{\prime} \\
S_{2 \text { Bid }}^{\prime} \\
S_{3 \text { Bid }}^{\prime} \\
S_{4 \text { iid }}^{\prime}
\end{array}\right]=\left[\begin{array}{llll}
\alpha_{11} & 0 & 0 & 0 \\
\alpha_{21} & 0 & 0 & 0 \\
\alpha_{31} & 0 & 0 & 0 \\
\alpha_{41} & 0 & 0 & 0
\end{array}\right] \cdot\left[\begin{array}{c}
S_{1 \text { вun }}^{\prime} \\
0 \\
0 \\
0
\end{array}\right] .
$$

From (52) we obtain four linear equations:

$$
\begin{aligned}
& S_{1 \text { iid }}^{\prime}=\alpha_{11} S_{1 \text { sun }}^{\prime} \\
& S_{2 \text { sid }}^{\prime}=\alpha_{21} S_{1 \text { sun }}^{\prime} \\
& S_{3 \text { sid }}^{\prime}=\alpha_{31} S_{1 \text { sun }}^{\prime} \\
& S_{4 \text { sid }}^{\prime}=\alpha_{41} S_{1 \text { sun }}^{\prime} .
\end{aligned}
$$

From (53) we determine the coefficients of the first column of matrix (29):

$$
\alpha_{11}=\frac{S_{1 \text { sid }}^{\prime}}{S_{1 \text { sun }}^{\prime}} ; \alpha_{21}=\frac{S_{2 \text { sid }}^{\prime}}{S_{1 \text { вun }}^{\prime}} ; \alpha_{31}=\frac{S_{3 \text { sid }}^{\prime}}{S_{1 \text { sun }}^{\prime}} ; \alpha_{41}=\frac{S_{4 \text { iid }}^{\prime}}{S_{1 \text { sun }}^{\prime}} .
$$

The Stokes parameters of the reflected wave $S_{16 i \delta}^{\prime}, S_{2 \beta i d}^{\prime}, S_{3 в i d}^{\prime}, S_{46 i \partial}^{\prime}$ are measured by the ship's radar, and the Stokes parameter $S_{1 \text { sиn }}^{\prime}$ is known in advance, so the coefficients of the first column of the matrix are easily measured experimentally and their values are displayed on the ship's radar computer.

To determine the coefficients of the second column of the matrix (29), the atmospheric object is irradiated with an electromagnetic wave of linear vertical polarization for which the equation (15) is written in the form: 


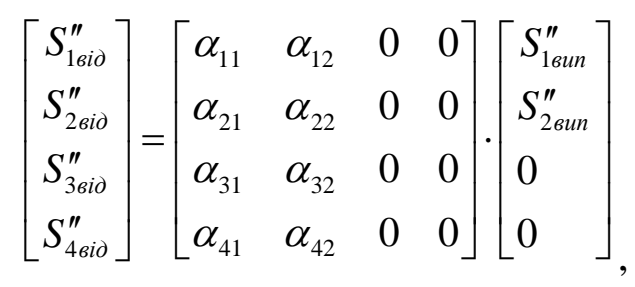

and the linear equations from (55) are written in the form:

$$
\begin{aligned}
& S_{1 \text { вid }}^{\prime \prime}=\alpha_{11} S_{1 \text { вun }}^{\prime \prime}+\alpha_{12} S_{2 \text { вun }}^{\prime \prime} \\
& S_{2 \text { вid }}^{\prime \prime}=\alpha_{21} S_{1 \text { вun }}^{\prime \prime}+\alpha_{22} S_{2 \text { вun }}^{\prime \prime} \\
& S_{3 \text { вid }}^{\prime \prime}=\alpha_{31} S_{1 \text { вun }}^{\prime \prime}+\alpha_{32} S_{2 \text { вun }}^{\prime \prime} \\
& S_{4 \text { вid }}^{\prime \prime}=\alpha_{41} S_{1 \text { вun }}^{\prime \prime}+\alpha_{42} S_{2 \text { вun }}^{\prime \prime},
\end{aligned}
$$

from which the coefficients of the second column of the matrix (29) are determined:

$$
\alpha_{12}=\frac{S_{1 \text { sid }}^{\prime \prime}}{S_{1 \text { sun }}^{\prime \prime}}-\alpha_{11} ; \alpha_{22}=\frac{S_{2 \text { sid }}^{\prime \prime}}{S_{1 \text { sun }}^{\prime \prime}}-\alpha_{21} ; \alpha_{32}=\frac{S_{3 \text { sid }}^{\prime \prime}}{S_{1 \text { sun }}^{\prime \prime}}-\alpha_{31} ; \alpha_{42}=\frac{S_{4 \text { sid }}^{\prime \prime}}{S_{1 \text { sun }}^{\prime \prime}}-\alpha_{41},
$$

where $S_{1 \text { sun }}^{\prime \prime}=S_{2 \text { виn }}^{\prime \prime}$, and the matrix coefficients $\alpha_{11}, \alpha_{21}, \alpha_{31}, \alpha_{41}$ are defined in relation (54).

To determine the coefficients of the third column of the matrix (15), the atmospheric object should be irradiated with an electromagnetic wave of the linear polarization with the angle of inclination of the field vector $45^{\circ}$. For such a wave $S_{1 \text { sun }}^{\prime \prime \prime}=S_{3 \text { sun }}^{\prime \prime \prime}$ and by analogy with (57), the coefficients of the third column of the matrix (15) are determined by the relations:

$$
\alpha_{13}=\frac{S_{1 \text { sid }}^{\prime \prime \prime}}{S_{1 \text { sun }}^{\prime \prime \prime}}-\alpha_{11} ; \alpha_{23}=\frac{S_{2 \text { sid }}^{\prime \prime \prime}}{S_{1 \text { sun }}^{\prime \prime \prime}}-\alpha_{21} ; \alpha_{33}=\frac{S_{3 \text { sid }}^{\prime \prime \prime}}{S_{1 \text { sun }}^{\prime \prime \prime}}-\alpha_{31} ; \alpha_{43}=\frac{S_{4 \text { sid }}^{\prime \prime \prime}}{S_{1 \text { sun }}^{\prime \prime \prime}}-\alpha_{41} .
$$

The irradiation of an atmospheric object by an electromagnetic wave of circular polarization allows us to determine the fourth column of the matrix (15), taking into account that $S_{1 \text { виn }}^{\prime \prime \prime \prime}=S_{4 \text { виn }}^{\prime \prime \prime \prime}$, then by analogy with (57):

$$
\alpha_{14}=\frac{S_{1 \text { sid }}^{\prime \prime \prime \prime}}{S_{1 \text { вun }}^{\prime \prime \prime \prime}}-\alpha_{11} ; \alpha_{24}=\frac{S_{2 \text { sid }}^{\prime \prime \prime \prime}}{S_{1 \text { uun }}^{\prime \prime \prime \prime}}-\alpha_{21} ; \alpha_{34}=\frac{S_{3 \text { sid }}^{\prime \prime \prime \prime}}{S_{1 \text { sun }}^{\prime \prime \prime \prime}}-\alpha_{31} ; \alpha_{44}=\frac{S_{4 \text { sid }}^{\prime \prime \prime \prime}}{S_{1 \text { uun }}^{\prime \prime \prime \prime}}-\alpha_{41} .
$$

As a result of sequential irradiation of an atmospheric object with the electromagnetic waves of four fixed polarizations and measurement of Stokes parameters of the reflected wave, for each polarization of the irradiated wave, the scattering matrix of the atmospheric object, which characterizes its reflection properties, is fully determined. Discrepancies in the coefficient values of the matrices of certain atmospheric formations are used in the methodology of their identification as well as for solving the problem of polarization selection of navigation objects located in the area of the atmospheric formation. Emission of an electromagnetic wave of a certain polarization is carried out automatically according to a certain program, and the whole process of measuring matrix coefficients is several seconds, which is within the limits of changes in the physical state of the internal structure of the atmospheric object. 


\section{Conclusions and prospects for further work in this area}

The functional connections between the ship's radar and the atmospheric environment are considered. The basic information flow for any moment of time, formed by the atmospheric environment in which there is a navigational object and represented in the form of three matrices, is established.

The model of interaction between the ship's radar and the atmospheric environment is implemented, the reflective properties of which are determined by the theoretical and experimental study of the Mueller matrix coefficients that carry all information about the atmospheric environment. In modeling the reflecting properties of the atmospheric formation, the actual Stokes energy parameters are used.

The theoretical calculation of the Muller matrix coefficients is shown to be a difficult task, so the method of their experimental measurement with the ship's radar is presented. However, the functional construction of the ship's radar should allow to emit and receive an electromagnetic wave of any polarization with the formation of Stokes parameters both for emission and reception. Therefore, further research in this direction will be devoted to the development of a functional scheme of the ship's polarization radar with the automatic processing and presentation of the received information, which will allow to separate the navigation object echo-signal from the atmospheric environment echo-signal.

\section{REFERENCES}

1. Putyatin V.G. Radiolokatsionnoye raspoznavaniye navigatsionnykh obyektov na puti sudna po polyarizatsionnym parametram elektromagnitnoy volny / V.G. Putyatin. D.M. Korban. S.Yu. Gudenko i dr // Matematichni mashini i sistemi. 2017. - №4. - S.120-128.

2. Akinshin R.N. Model matrichnoi vzaimnokorrelyatsionnoi funktsii zondiruyushchego i otrazhennogo vektornykh signalov dlya kontseptualnogo proyektirovaniya radiolokatora $\mathrm{s}$ sintezirovannoi aperturoi na vozdushnom nositele /Akinshin R.N.. Esikov O.V. Zatuchnyi D.A.. Peteshov A.V. // Nauchnyy vestnik MGTU GA. 2019; 22(2):86-95. https://doi.org/10.26467/2079-0619-2019-22-2-86-95

3. Zalevskiy A.P. Otsenka effektivnosti prostranstvenno-vremennoy i vremya-prostranstvennoy filtratsii signalov v kogerentno-impulsnykh RLS / Zalevskiy A.P. Piza D.M. Presnyak I.S. Sirenko A.S. // Radioyelektronika. Informatika. Upravlinnya. - Zaporizhzhya: ZNTU. 2012. №2. - S.39-44.

4. Putyatin V. G. Matritsa rasprostraneniya radiolokatsionnogo informatsionnogo kanala pri radiolokatsionnom nablyudenii navigatsionnykh obyektov na puti sudna / Putyatin V.G. Korban D.V. Knyaz A.I. // Matematicheskiye mashiny i sistemy. 2018. - №2. - S.141-147.

5. Metody priblizhennogo resheniya zadachi Koshi: Uchebnoye posobiye / K.V. Grigoryeva. S. E. Mikheyev. - SPb: SPb GU. 2010. - s.56.

6. Verba V. S., Neronskiy L. B., Osipov I. G., Turuk V. E. Radiolokacionnie sistemi zemleobzora kosmitcheskogo bazirovaniya [Space Based Radar Surveillance Systems]. Pod red. V.S. Verbi. M.: Radiotehnika, 2010, 680 s.

7. Botov M. I., Vyahirev V. A., Devotchak V. V. Vvedenie v teoriyu radiolokatcionnih sistem: monografiya. [Introduction to the theory of radar systems: monograph]. Pod red. M.I. Botova. Krasnoyarsk: Sib. federal. un-t, 2012, 394 s.

8. Akhiyarov V. V., Nefedov S. I., Nikolaev A. I. Radiolokaczionny`e sistemy`. [Radar systems]. Pod red. A.I. Nikolaeva. 2-e izd., M.: Izd. MGTU im. N.E`. Baumana, 2018, 349 s. ISBN 9785-7038-4823-4.

9. Korban D.V., Volkov A.N., Korban V.Kh., Degtyareva L.N. Ispolzovaniye matritsy kogerentnosti chastichno polyarizovannoy volny dlya povysheniya effektivnosti 
radiolokatsionnogo nablyudeniya obyektov//Tsifrovyye tekhnologii. ONAZ im.O.S.Popova. Odesa. - №23. 2018. - S.131-142.

10. Korban D.V. Burmaka I.O. Kintsevomirni rozpodili pri radiolokatsiynomu sposterezhenni navigatsiynikh ob'єktiv / Korban D.V. Burmaka I.O. // Sudnovodinnya: Zb. nauk. prats/ NU «OMA». Vip. 29. - Odesa: E 89 «VidavInform». 2019. - S. 106 - 115.

11. William L. Melvin; James A. Scheer Principles of Modern Radar: Volume 3: Radar Applications, Institution of Engineering \& Technology,2013. - 820 p. ISBN: 9781891121548.

12. Richard Klemm; Ulrich Nickel; Christoph Gierull; Pierfrancesco Lombardo; Hugh Griffiths; Wolfgang Koch Novel Radar Techniques and Applications Volume 1: Real Aperture Array Radar, Imaging Radar, and Passive and Multistatic Radar, Institution of Engineering \& Technology, 2017. - 951 p. ISBN: 9781613532256.

13. Richard Klemm; Ulrich Nickel; Christoph Gierull; Pierfrancesco Lombardo; Hugh Griffiths; Wolfgang Koch Novel Radar Techniques and Applications Volume 2: Waveform Diversity and Cognitive Radar, and Target Tracking and Data Fusion, SciTech Publishing, 2017 - 553 p. ISBN: 9781613532263.

14. Michael C. Wicks; Eric L. Mokole; Shannon D. Blunt; Richard S. Schneible; Vincent J. Amuso Principles of Waveform Diversity and Design, Scitech Publishing, 2011 - 1228 p. ISBN: 9781891121951.

15. Clive Alabaster Pulse Doppler Radar: Principles, technology, applications, SciTech Publishing Inc, United States, 2012. - 420 p. ISBN: 9781891121982 